\title{
Thermal and probiotic treatment effects on restaurant waste for incorporation into poultry diet
}

\author{
Sadegh Cheraghi Saray • Ali Hosseinkhani • \\ Hossein Janmohammadi • Peyman Zare • \\ Hossein Daghighkia
}

Received: 8 January 2014/Accepted: 24 July 2014/Published online: 7 August 2014

(C) The Author(s) 2014. This article is published with open access at Springerlink.com

\begin{abstract}
Background Restaurant waste (RW) can be considered as a valuable feedstuff for animal nutrition due to its high nutritional value and low price. The aim of this study was to determine nutritional value and the microbial load of the waste in order to incorporate it in the poultry feedstuff. To our knowledge the current study is the first attempt in the field of RW processing with Lactobacillus strains. Then the second goal of this experiment was to study the effect of RW processing with Lactobacillus on nutrient and chemical composition of RW. The four Lactobacillus strains applied in the study included Lactobacillus casei subsp1608 ATCC 39392, Lactobacillus plantarum-1058 ATCC 8014, Lactobacillus acidophilus-1643 DSM 20079 and Lactobacillus reuteri-1655 DSM 20016.

Results The experiments in the case of chemical composition showed that the mixed processing caused a significant improvement in nutritional value compared to the raw waste $(P<0.05)$. Among the strains, L. acidophilus had the highest mean amount of crude protein (CP), ether extract (EE), dry matter and gross energy (GE) with 21.40, 19.91, 41.02 and $4,872.61 \mathrm{kcal} / \mathrm{kg}$, respectively, and the lowest amount of ash $(3.67 \%)$ compared with other strains. In the second phase of the experiment, the results obtained from comparing the average total count of bacteria and coliforms in five types of RW proved that the means of both bacteria
\end{abstract}

S. Cheraghi Saray · A. Hosseinkhani $(\square) \cdot$ H. Janmohammadi · H. Daghighkia

Department of Animal Science, Faculty of Agriculture,

University of Tabriz, Tabriz, Iran

e-mail: hosseinkhani2000@yahoo.com

P. Zare

Department of Pathobiology, Faculty of Veterinary Medicine, University of Tabriz, Tabriz, Iran and coliforms are within the standard range and can be applied as poultry feed. However, regarding the average total count of bacteria, barbecue waste with $9.85 \times 10^{4}$ CFU/g and chicken waste with $9.51 \times 10^{3} \mathrm{CFU} / \mathrm{g}$ were the most contaminated and the healthiest foods, respectively. In addition, barbecue waste with $1.28 \times 10^{2} \mathrm{CFU} / \mathrm{g}$ and fish waste with $1.08 \times 10^{2} \mathrm{CFU} / \mathrm{g}$ had the highest and lowest count of coliforms, respectively.

Conclusion Nutritional value determination of RW samples showed that it is in the level that can be used in poultry diet. It was also presented that by adding Lactobacillus strains to the waste, the amount of GE, CP and EE increased and ash amount decreased. Therefore, its use in poultry diet is highly economic. In addition, this study showed that RW microbial load is in the level that can be applied as poultry feedstuff.

Keywords Probiotic - Nutritional value $\cdot$ Bacterial contamination $\cdot$ Restaurant waste $\cdot$ Processing method
Abbreviations
RW Restaurant waste
$\mathrm{CP}$ Crude protein
EE Ether extract
DM Dry matter
OM Organic matter
GE Gross energy
CF Crude fiber
NFE Nitrogen free extract
ME Metabolizable energy

\section{Introduction}

Continuous rise of feed costs has forced livestock producers to find alternative choices for traditional feedstuffs. 
Restaurant waste (RW) is the leftover which can no longer be used in restaurants and hotels. Since it has high nutritional value and low price, RW can be considered as a valuable feedstuff for animal nutrition (Kojima 2005). Soliman et al. (1978) studied nutritional value of RW. They reported the values of $7.5,21.6,16.6,4.6,31.6,18.3,5.2$ and 1.4 percent for moisture, crude protein (CP), ether extract (EE), crude fiber (CF), nitrogen free extract (NFE), ash, calcium and phosphorus content of RW, respectively. Furthermore, Moradi (2012) calculated dry matter (DM), organic matter (OM), ash, $\mathrm{CP}, \mathrm{EE}, \mathrm{CF}$ and metabolizable energy (ME) of RW as following: 33.4, 95.9, 4.1, 15.1, $14.1,12.3$ percent and $3,270 \mathrm{kcal} / \mathrm{kg}$, respectively. However, RW usage encountered some serious limitations because of its high potential to decay. Heat processing is one of the effective ways of reducing microbial contamination of feed. Sancho et al. (2004) suggested that food residual thermally processed at $65^{\circ} \mathrm{C}$ for 20 min could be used as animal feed. However, due to high cost of heat processing, alternative methods can be considered.

Probiotics are microbial-biological sources which can be used for food processing (Kosin and Rakshit 2006). Probiotics usage alone or in mixed cultures can improve the nutritional value of the feedstuffs. They can also improve amino acid utilization through lowering protein degradation (Mikulec et al. 1999). Some Lactobacillus strains are capable of producing antimicrobial components when cultured on specific media (Jin et al. 1998). Avall-Jaaskelainen and Palva (2005) and Parvez et al. (2006) reported that Lactobacilli have antimicrobial effects and by producing some metabolites such as lactic acid, can restrict development of gram-positive and negative pathogens.

Rice grain is the main portion of meals served in Iranian restaurants; hence it comprises the highest proportion in the Iranian RW. During the cooking process, its moisture and fat content can be increased considerably. A supplementary foodstuff (called "Khoresht") mainly consists of meat, peas, potatoes, tomatoes, onion and vegetables. However, depending on the type of Khoresht, the amount of nutrients, smell and flavor of RW can be variable.

Poultry's consuming RW has the risk of infection all the time because RW has high moisture and it must be used in a short period of time. In the divisions taken place according to food codex, the products containing meat and protein are among the high risk foods because the conditions required for bacteria to grow are present in them. According to the studies conducted all over the world, the accepted method to control the quality and hygiene of the cooked food is to use microbial standards. To assure the hygiene of the cooked food, Little et al. (2003) recommended some necessary experiments including the total count of bacteria, the count of coliforms especially E. coli and the count of pathogenic bacteria such as
Staphylococcus aureus, Salmonella, Listeria monocytogenes and Clostridium perfringens.

The aim of the present study was to determine nutritional value and microbial load of the waste in order to incorporate it in poultry feedstuff. To our knowledge, the current study is the first attempt in the field of RW processing with Lactobacillus strains. Then the second goal of this experiment was to study the effect of RW processing with Lactobacillus on nutrient and chemical composition of RW.

\section{Methods}

\section{Sample preparation}

The RW was obtained from the central restaurant of Tabriz university. In a period of 2 weeks, the fresh waste samples (78.7\% moisture) were collected daily and each meal sample was mixed with that of the other meals in an equal amount to keep the effect of each food. After gaining a homogeneous sample with an electric blender, the samples were divided into five parts (each part was $1 \mathrm{~kg}$ ). One part as the control group (without any thermal processing) was dried in air conditions at room temperature and the other four experimental treatment groups were oven-dried at $60{ }^{\circ} \mathrm{C}$ for $20 \mathrm{~min}$. Then the samples were immediately stored at $-18{ }^{\circ} \mathrm{C}$ for later analysis (Westendorf et al. 1998). The laboratory studies were performed in the laboratories of faculty of veterinary medicine and faculty of agriculture of the University of Tabriz.

\section{Lactobacillus culture preparation}

Four Lactobacillus strains including Lactobacillus casei subsp-1608 ATCC 39392, Lactobacillus plantarum-1058 ATCC 8014, Lactobacillus acidophilus-1643 DSM 20079 and Lactobacillus reuteri-1655 DSM 20016 were used for microbial processing of RW. According to Jin et al. (1998) for each experiment, Lactobacillus strains were inoculated separately into Man, Rogosa, and Sharpe (MRS) broth and incubated at $37^{\circ} \mathrm{C}$ for $24 \mathrm{~h}$, after which the bacterial cells were harvested by centrifugation at $2,000 \times g$ for $10 \mathrm{~min}$ at $4{ }^{\circ} \mathrm{C}$. To obtain a concentration of $1 \times 10^{8}$ cells/gram feed, the bacterial pellets were diluted with appropriate amounts of phosphate buffer solution (PBS), based on their original CFUs per gram determined on MRS agar. The freshly prepared bacterial suspensions were mixed into the feed each day to ensure viable bacterial cells in the feed throughout the experimental period. The viability of the bacterial cells was checked by MRS agar cultures to ensure that the concentration of the viable bacterial cells remained at $1 \times 10^{8}$ cells/gram feed. 
Experimental groups and feed treatments

Experimental treatment groups included one negative control group (no process) and four heat and microbial treated groups. The samples were ground and blended together homogeneously for thermal and microbial processing. Then they were divided into four parts and kept into an oven for $20 \mathrm{~min}$ at $80{ }^{\circ} \mathrm{C}$ to remove the microbial contamination. Then, $5 \mathrm{ml}$ of bacterial suspension of each strain was added to the RW samples and completely mixed in order to make uniform samples. The samples were kept at $37{ }^{\circ} \mathrm{C}$ of incubator for $24 \mathrm{~h}$.

Chemical analysis

The CP, DM, ash and EE content of the samples were determined based on AOAC (1990) and the GE content was measured using Labisco Adiobatic bomb calorimeter.

Microbiological evaluation

To evaluate the microbial contamination of different kinds of RW (from distinct meals), the samples were collected during four continuous weeks and the average count of bacteria and coliforms were determined according to APHA and FDA procedures (Vanderzant and Splittstoesser 1992). The pour plate method was applied for calculation of total count of bacteria and the coliforms were enumerated by a violet red bile agar (VRBA) plate and brilliant green lactose bile broth (BGLB).

Data analysis

The statistical analysis was performed using the GLM procedure of SAS (2003) in one-way ANOVA design. Mean values were compared by Duncan multiple range test $(P<0.05)$ and Corr procedure was used to calculate the correlation coefficients.

\section{Results}

Chemical analysis

The average chemical composition of RW is reported in Table 1. Processing RW samples with $L$. acidophilus and $L$. reuteri increased the DM content compared to the control group $(P<0.05)$. The DM of the RW in the present study was $38.78 \%$. Also microbial processing of RW improved CP content in all treated groups compared to the control group; however the L. acidophilus and L. reuteri had the highest amount of CP content $(P<0.05)$.
Table 1 Chemical composition of restaurant waste in the experimental groups

\begin{tabular}{llllll}
\hline & $\begin{array}{l}\text { GE } \\
(\mathrm{kcal} / \mathrm{kg})\end{array}$ & $\begin{array}{l}\text { CP } \\
(\%)\end{array}$ & $\begin{array}{l}\text { DM } \\
(\%)\end{array}$ & EE (\%) & $\begin{array}{l}\text { Ash } \\
(\%)\end{array}$ \\
\hline L. acidophilus & $4,872.61^{\mathrm{a}}$ & $21.4^{\mathrm{a}}$ & $41.02^{\mathrm{a}}$ & $19.91^{\mathrm{a}}$ & $3.67^{\mathrm{d}}$ \\
L. casei & $4,625.47^{\mathrm{c}}$ & $19.51^{\mathrm{b}}$ & $38.67^{\mathrm{c}}$ & $19.2^{\mathrm{b}}$ & $3.90^{\mathrm{c}}$ \\
L. plantarum & $4,577.29^{\mathrm{c}}$ & $19.95^{\mathrm{b}}$ & $38.87^{\mathrm{c}}$ & $19.01^{\mathrm{bc}}$ & $4.02^{\mathrm{b}}$ \\
L. reutri & $4,784.57^{\mathrm{b}}$ & $21.13^{\mathrm{a}}$ & $40.02^{\mathrm{b}}$ & $19.72^{\mathrm{a}}$ & $3.71^{\mathrm{d}}$ \\
Control & $4,507.33^{\mathrm{d}}$ & $18.87^{\mathrm{c}}$ & $38.78^{\mathrm{c}}$ & $18.84^{\mathrm{c}}$ & $4.12^{\mathrm{a}}$ \\
Mean & 4,673 & 20.17 & 39.47 & 19.34 & 3.88 \\
SEM & 19.52 & 0.18 & 0.16 & 0.07 & 0.03 \\
\hline
\end{tabular}

Means within a column with no common superscript differ significantly $(P<0.05)$

Data are from $n=5$ replicate for each sample

Table 2 Correlation coefficient among chemical compositions of restaurant waste samples

\begin{tabular}{lccccc}
\hline & DM & Ash & CP & EE & GE \\
\hline DM & 1.00 & -0.69 & 0.88 & 0.78 & 0.76 \\
$P$ value & - & 0.0001 & 0.0001 & 0.0001 & 0.0001 \\
Ash & -0.69 & 1.00 & -0.83 & -0.088 & -0.095 \\
$P$ value & $0.0001 *$ & - & 0.0001 & 0.0001 & 0.0001 \\
CP & 0.88 & -0.83 & 1.00 & 0.87 & 0.89 \\
$P$ value & 0.0001 & 0.0001 & - & 0.0001 & 0.0001 \\
EE & 0.78 & -0.88 & 0.87 & 1.00 & 0.93 \\
$P$ value & 0.0001 & 0.0001 & 0.0001 & - & 0.0001 \\
GE & 0.76 & -0.95 & 0.89 & 0.93 & 1.00 \\
$P$ value & 0.0001 & 0.0001 & 0.0001 & 0.0001 & - \\
\hline
\end{tabular}

Replicate for each sample was 5

Asterisk indicates $P<0.0001$

The results of this study showed that RW treated with $L$. acidophilus, $L$. reuteri and $L$. casei had higher fat than control group $(P<0.05)$, while in the L. plantarum treated $\mathrm{RW}$ and control group, the amount of fat was the same. The control group had the highest amount of ash content among experimental groups $(P<0.05)$, and the GE values of all treated samples were higher than those of the control group $(P<0.05$; Table 1$)$.

The correlation coefficients among chemical compositions of experimental groups are shown in Table 2. Crude ash had negative correlation with GE and $\mathrm{CP}(P<0.01)$ and it also had high correlation between $\mathrm{EE}$ and GE $(r=0.93)$.

\section{Microbial contamination}

The results of evaluation in terms of microbial contamination revealed that the average total number of bacteria was in the normal range $\left(10^{5} \mathrm{CFU} / \mathrm{g}\right)$ and the highest and 
Table 3 The average total count of bacteria (CFU/g) in five selected food waste of different types

\begin{tabular}{lllllll}
\hline & Mince & Chicken & Fish & Roasted chicken & Barbecue & Mean \\
\hline 1st w sample & $6.42 \times 10^{2}$ & $1.90 \times 10^{4}$ & $2.59 \times 10^{4}$ & $5.31 \times 10^{2}$ & $1.27 \times 10^{5}$ & $\left(3.46 \times 10^{4}\right)^{\mathrm{a}}$ \\
2nd w sample & $1.36 \times 10^{5}$ & $5.24 \times 10^{2}$ & $3.84 \times 10^{2}$ & $2.56 \times 10^{2}$ & $4.30 \times 10^{3}$ & $\left(3.33 \times 10^{4}\right)^{\mathrm{a}}$ \\
3rd w sample & $3.15 \times 10^{4}$ & $1.62 \times 10^{4}$ & $2.28 \times 10^{3}$ & $3.78 \times 10^{3}$ & $1.22 \times 10^{5}$ & $\left(3.51 \times 10^{4}\right)^{\mathrm{a}}$ \\
4th w sample & $7.26 \times 10^{3}$ & $2.34 \times 10^{3}$ & $1.06 \times 10^{4}$ & $1.12 \times 10^{5}$ & $1.44 \times 10^{5}$ & $\left(5.46 \times 10^{4}\right)^{\mathrm{a}}$ \\
Mean & $\left(4.38 \times 10^{4}\right)^{\mathrm{ab}}$ & $\left(9.51 \times 10^{3}\right)^{\mathrm{b}}$ & $\left(9.79 \times 10^{3}\right)^{\mathrm{b}}$ & $\left(3.54 \times 10^{4}\right)^{\mathrm{ab}}$ & $\left(9.85 \times 10^{4}\right)^{\mathrm{a}}$ \\
\hline
\end{tabular}

Means within a row and column with no common superscript differ significantly $(P<0.05)$

Table 4 The average count of coliforms (CFU/g) in five selected food waste of different types

\begin{tabular}{lllllll}
\hline & Mince & Chicken & Fish & Roasted chicken & Barbecue & Mean \\
\hline 1st w sample & $1.23 \times 10^{2}$ & $1.27 \times 10^{2}$ & $1.33 \times 10^{2}$ & $1.19 \times 10^{2}$ & $1.2 \times 10^{2}$ & $\left(1.24 \times 10^{2}\right)^{\mathrm{a}}$ \\
2nd w sample & $1.21 \times 10^{2}$ & $1.13 \times 10^{2}$ & $9.4 \times 10^{1}$ & $1.42 \times 10^{2}$ & $9.3 \times 10^{1}$ & $\left(1.12 \times 10^{2}\right)^{\mathrm{a}}$ \\
3rd w sample & $9.7 \times 10^{1}$ & $9.8 \times 10^{1}$ & $9.1 \times 10^{1}$ & $8.8 \times 10^{1}$ & $1.67 \times 10^{2}$ & $\left(1.08 \times 10^{2}\right)^{\mathrm{a}}$ \\
4th w sample & $1.26 \times 10^{2}$ & $10^{2}$ & $1.15 \times 10^{2}$ & $9.6 \times 10^{1}$ & $1.32 \times 10^{2}$ & $\left(1.13 \times 10^{2}\right)^{\mathrm{a}}$ \\
Mean & $\left(1.16 \times 10^{2}\right)^{\mathrm{a}}$ & $\left(1.09 \times 10^{2}\right)^{\mathrm{a}}$ & $\left(1.08 \times 10^{2}\right)^{\mathrm{a}}$ & $\left(1.11 \times 10^{2}\right)^{\mathrm{a}}$ & $\left(1.28 \times 10^{2}\right)^{\mathrm{a}}$ \\
\hline
\end{tabular}

Means within a row and column with no common superscript differ significantly $(P<0.05)$

lowest number were for barbecue (Kebab) waste and chicken waste, respectively $(P<0.05$; Table 3$)$. The average counts of coliforms was a little higher than standard, $\left(10^{2} \mathrm{CFU} / \mathrm{gram}\right)$. However, no significant differences were observed among experimental groups (Table 4).

\section{Discussion}

The DM of the RW in the present study $(38.78 \%)$ was higher than reports of Walker et al. (2002) with $37.46 \%$, Kjos et al. (2000) with $21.4 \%$ and Moradi (2012) with $33.4 \%$. The CP content of RW was similar to the results of Saki et al. (2006); however, it was higher than the results of Moradi (2012) and Kojima (2005) with 15.1, $15.6 \%$, respectively. The other researchers (Walker et al. 1998, 2002, 2004; Kjos et al. 2000; Westendorf et al. 1998) reported higher amount of CP with 33.4, 29, 20, 49 and $21.4 \%$, respectively.

The variation in chemical composition of RW in different studies could be due to the use of different ingredients in preparing food, additives and cooking methods. In Iran, rice compromising the main part of food in restaurants. Therefore, the major part of RW is rice with leftover vegetables, cereals and stew.

Processing RW with Lactobacilli causes the production of some bacterial metabolites during proliferation like Bacteriocins as proteinaceous toxins (Ogunbanwo et al. 2003). Lactobacillus strains excrete several extra-cellular enzymes which could digest the nutrients such as RW.
Then, the existing microorganisms on the surface of RW can use these materials for their growth and proliferation.

Increasing the microbial mass during the processing can increase the $\mathrm{CP}$ content in the final product. Also some part of higher $\mathrm{CP}$ content in microbial processed RW can be due to the production of Bacteriocins during the proliferation period. Kailasapathy (2002) and Angel et al. (2005) suggested that, microorganisms could use structural carbohydrates of food as a source of energy and using nitrogenous compound can produce their own needed protein. So, microbial processing of RW can enrich it by biological conversion method. Moreover, most of the Lactobacillus strains contain a S-layer composed of protein and glycoprotein units. S-layer is known as a protective stratum which preserves the cell shape and traps the ions and molecules in the ectoblast of membrane of bacteria. As Lactobacillus grows in the processed medium, the number of S-layer gets increased. It also increases the protein content of the processed food (Frece et al. 2005).

Frece et al. (2005) demonstrated that $L$. acidophilus has more proteolytic activity compared with the other Lactobacilli. Due to this feature, it can produce more nitrogenous compounds which are necessary ingredients for bacterial growth. Availability of free nitrogen through proteolysis can enhance bacterial population by producing more $\mathrm{Bac}$ teriocin and increasing the number of S-layer. These phenomena can increase the protein content of the processed feed. Therefore, the higher CP content of RW which was processed by $L$. acidophilus in the present study can be a result of this function (Table 1). 
Kafilzadeh and Safariparvar (2003) reported that the positive effects of feed supplementation with Lactobacillus spp. could be due to several factors including: supplying some nutrients such as vitamins, producing some digestive enzymes, destroying pathogenic bacteria and neutralizing their toxins by producing organic acids and Bacteriosins. Zhang et al. (2003) suggested that Lactobacillus could improve nitrogen retention and nutrient absorption especially fatty acids and glucose, therefore they could be considered as a growth promoter for improvement of the livestock performance.

EE or fat content of RW in the present study (18.84\%) was less than some reports (Westendorf et al. 1998 with $27.2 \%$ and Kjos et al. 2000 with $33 \%$ ). However, it was higher than the other reports (Walker et al. 2002; Saki et al. 2006; Moradi 2012 with 15.4, 10.58 and $15.1 \%$, respectively). The foodstuff, supplied oil and cooking method can influence the amount of fat in the RW.

The difference in the amount of fat among Lactobacillus strains primarily could be due to their different growth behavior in different conditions. Bagley et al. (2005) suggested that, Lactobacillus spp. bacteria grew conveniently in MRS- Sorbitol- Agar and MRS- Salicin- Agar cultures in laboratory conditions and create clear and large colonies by fermentation of the existing carbohydrates. However, when the same strains are cultured in different mediums, their purity and efficacy could be different. Regarding the fact that membrane of cellular organelles and the whole membrane systems existing in the cells are made of Lipoproteins (two layers of phospholipid and a layer of protein), by increasing bacterial mass during the processing, the amount of phospholipids increases as well. Probably, more growing strains could have more cellular mass and fat content.

Different bacterial strains have different ability in destroying pathogenic strains. L. acidophilus and L. reuteri produce Lactacins and Reuterin (a $\beta$-3-HPA compound derived from glycerol), respectively, which have a vast functional effect against gram negative and positive bacteria and can destroy the pathogenic bacteria more effectively than the other strains (Casas Ivan and Dobrogosz Walter 2000; Parvez et al. 2006). Therefore, the higher amount of fat and other nutrients in these two groups is not so much surprising. Kailasapathy (2002) demonstrated that when Lactobacillus is injected to a sterile food, the immunity challenge to overcome the pathogenic strains does not happen, therefore, the energy requirements decrease. In this case, the extra accessible energy could shift for fat synthesis.

Samarasinghe et al. (2003) reported increased fat content with supplemented Virginiamycin, while Sabatkova et al. (2008) observed no difference in the amount of EE in diets containing antibiotic and incorporated with three strains of probiotic. The variation in different reports could be due to the composition of substrates and the amount of fat existing in food.

Saki et al. (2006) reported lower GE than our results $(4,300$ vs. $4,507 \mathrm{kcal} / \mathrm{kg})$. The higher amount of $\mathrm{GE}$ in all of the processed treatments comparing the control group reflects the higher content of nutrients in these groups which originated from the proliferation of Lactobacillus strains. Avall-Jaaskelainen and Palva (2005) reported that organic acid produced by Lactobacillus can probably prevent the growth of pathogenic microorganisms and increase energy content in the processed food. Also, Missotten et al. (2007) reported increased amount of lactic acid and exoenzymes production after the addition of probiotic to carrot waste.

According to the results of present study, higher amounts of $\mathrm{CP}$ and $\mathrm{EE}$ in experimental treatments, can increase GE content, however, it should be noticed that the GE is not a good criterion for accessible energy of the feedstuffs by the animal (Walker et al. 2004).

Saki et al. (2006) reported higher amount of ash compared to the current study (6.29 vs. $4.12 \%)$. Higher amount of ash resulted in lower value of organic matter and subsequently decrease in the content of GE. Some researchers previously reported negative correlation between the ash with CP and EE content (Westendorf et al. 1998; Walker et al. 2002). Considering the high correlation between EE and GE $(r=0.93)$, the main reason for difference among GE of experimental treatments could be their different amounts of EE. Therefore, the higher amount of GE in all of the processed treatments can be explained by higher bacterial population and consequently increased amount of EE and CP content of them (Table 2).

The results of evaluation in terms of microbial contamination showed the highest total count was for barbecue (Kebab) waste. Improper heating during the cooking process may be the main reason for higher bacterial counts in the kebab. Cooking method for kebab is direct heating for a short time, and there is not enough time for removal of the contaminant bacteria. Tessi et al. (2002) mentioned that longer heating time can provide more safety margin for food.

This experiment revealed that microbial contamination of RW is in an acceptable range for use as poultry feed. Probably, a simple and economic processing of RW (i.e. thermal processing) can overcome the anxiety about probable infection.

Tessi et al. (2002) studied 101 samples of cooked and ready to serve food in a central school kitchen in Argentina and found that the average of bacterial and coliform contamination were $3.63 \times 10^{4}$ and $1.90 \times 10^{2} / \mathrm{g}$, respectively. He separated $6.34 \%$ E. coli from the samples. Furthermore, Fang et al. (2003) studied 164 samples of 
cooked food waste in Taiwan. He reported contamination rates 27.5, 17.9, 7.9 and $4.98 \%$ for coliforms, Staphylococcus aureus, E. coli and Bacillus cereus, respectively.

Fang et al. (2003) reported that favorite thermal range for growth of Salmonella, bacteria and fungi is $5-55{ }^{\circ} \mathrm{C}$. Raising temperature to $60{ }^{\circ} \mathrm{C}$, caused the microorganisms to stop their development, however, microbial mass reduction follows a logarithmic pattern. Bacterial death rate depends on $\mathrm{pH}$ level as well as inner moisture. Proper $\mathrm{pH}$ for growth of Salmonella and bacteria is 7-8.5 and for fungi is 5-7. Supplementation of feed with different probiotic strains, can decrease microbial contamination through $\mathrm{pH}$ level.

Lactobacillus casei and L. plantarum strains are commonly used in feed manufacturing to improve feed quality and compete with decaying bacteria of the food and sometimes with pathogenic bacteria such as Staphylococcus aureus and Listeria monocytogenes (Ogunbanwo et al. 2003). Patterson and Burkholder (2003) indicated that coliform and clostridia had a negative influence on intestinal mucosa and nutrient absorption in the broilers. Therefore, it is suggested that these probiotics be used as a feed additive to RW.

Low dry matter content of RW makes it susceptible to microbial decay which is the main challenge in consuming these kinds of feed. However, Rameshi et al. (2007) reported that wet feed usage in broiler chicken rations, increased weight gain and improved feed efficiency. Considering high moist content of RW, the processing of feed containing RW with probiotics, not only prevents feed decay, but also improves broiler performance by increased digestibility and nitrogen retention.

\section{Conclusion}

The nutritional value determination of RW samples showed that it is in the level applicable in poultry diet and by adding Lactobacillus strains to the waste, GE, CP and EE increased and ash amount decreased. Among the Lactobacillus strains, L. acidophilus was the most efficient. The difference among the resulted contents for Lactobacilli strains in the current study is due to their different capabilities in producing different metabolites which are able to increase the nutritional value of the feed. Since there is not enough data in the case of RW microbial processing, it is suggested that other studies be carried out in this field to make RW use more applicable as poultry feed. It is also recommended that the effect of other microbial strains be investigated in order to find a strain which has the most efficient performance on RW. In addition, this study showed that RW microbial load is in the level that can be applied as poultry diet. Furthermore, one of the most important advantages of using Lactobacillus in RW is to turn the food which is fed to the broilers and consequently the food which human beings consume into healthy food. This privilege is more significant than its effect on poultry productive performance. Therefore, its use in poultry diet is highly economic.

Conflict of interest The authors declare that they have no competing interests.

Open Access This article is distributed under the terms of the Creative Commons Attribution License which permits any use, distribution, and reproduction in any medium, provided the original author(s) and the source are credited.

\section{References}

American Public Health Association (1992) Compendium of methods for the microbiological examination of foods, 3rd edn. APHA, Washington

Angel R, Dalloul RA, Doerr J (2005) Performance of broiler chickens fed diets supplemented with a direct-fed microbial. Poult Sci 84:1222-1231

AOAC (1990) Official methods of analysis, 15th Edn Vol 2. Association of Official Analytical Chemists, Washington, DC USA, p 587

Avall-Jaaskelainen S, Palva A (2005) Lactobacillus surface layers and their applications. FEMS Microbiol Rev 29:511-529

Bagley M, Cormac GMG, Colin H (2005) The interaction between bacteria and bile. FEMS Microbiol Rev 29:625-651

Casas Ivan A, Dobrogosz Walter J (2000) Validation of the probiotic concept: Lactobacillus reuteri confers broad spectrum protection against disease in humans and animals. Microb Ecol Health Dis $12: 247-285$

Fang TJ, Wei QK, Liao CW, Hung MJ, Wang TH (2003) Microbiological quality of 18 degrees $\mathrm{C}$ ready-to-eat food products sold in Taiwan. Int J Food Microbiol 80:241-250

Food and Drug Administration (FDA) (1992) Bacteriological analytical manual (1992) 6th Edn. Arlington VA, Published by association of official analytical chemists for FDA, Washington, $\mathrm{DC}$

Frece J, Kos B, Svetec IK, Zgaga Z, Mrsa V, Suskovic J (2005) Importance of S-layer proteins in probiotic activity of Lactobacillus acidophilus M92. J Appl Microbiol 98:285-292

Jin LZ, Ho YW, Abdullah N, Jalaludin S (1998) Growth performance, intestinal microbial populations, and serum cholesterol of broilers fed diets containing Lactobacillus cultures. Poult Sci 77:1259-1265

Kafilzadeh F, Safariparvar MR (2003) Effect of different levels of probiotic Imonobac on performance of broiler. J Agric Sci Nat Resour 9:173-184 In Persian

Kailasapathy K (2002) Microencapsulation of probiotic bacteria: technology and potential applications. Curr Issues Intest Microbiol 3:39-48

Kjos NP, Overland M, Arnkvarn-Bryhni E, Sorheim O (2000) Food waste products in diets for growing-finishing pigs: effect on growth performance, carcass characteristics and meat quality. Acta Agric Scand Sect A Anim Sci 50:193-204

Kojima S (2005) Dehydrated kitchen waste as a feedstuff for laying hens. Int J Poult Sci 4:689-694

Kosin B, Rakshit SK (2006) Microbial and processing criteria for production of probiotics: a review. Food Technol Biotechnol 44:371-379 
Little CL, Lock D, Barnes J, Mitchell RT (2003) Microbiological quality of food in relation to hazard analysis systems and food hygiene training in UK catering and retail premises. Commun Dis Public Health 6:250-258

Mikulec Z, Serman V, Mas N, Lukac Z (1999) Effect of probiotic on production results of fattened chickens fed different quantities of protein. Vet Arhiv 69:199-209

Missotten JAM, Michiels J, Goris J, Herman L, Heyndrickx M, De Smet S, Dierick NA (2007) Screening of two probiotic products for use in fermented liquid feed. Livest Sci 108:232-235

Moradi M (2012) Determination of nutritive value of restaurant waste and its effect on performance of finishing lambs. M.Sc. Thesis. University of Tabriz. In Persian

Ogunbanwo ST, Sanni AL, Onilude AA (2003) Characterization of bacteriocin produced by Lactobacillus plantarum F1 and Lactobacillus brevis OG1. Afr J Biotechnol 2:219-227

Parvez S, Malik KA, Ah Kang S, Kim HY (2006) Probiotics and their fermented food products are beneficial for health. J Appl Microbiol 100:1171-1185

Patterson JA, Burkholder KM (2003) Application of prebiotics and probiotics in poultry production. Poult Sci 82:627-631

Phillips M, Kailasapathy K, Tran L (2006) Viability of commercial probiotic cultures (L. acidophilus, Bifidobacterium sp. L. casei, L. paracasei and L. rhamnosus) in cheddar cheese. Int J Food Microbiol 108:276-280

Rameshi F, Eslami M, Fayazi J (2007) Effect of wet rations on performance of broiler chicken after feed restriction in compensatory growth. Pajouhesh Sazandegi 74:46-52 In Persian

Sabatkova J, Kumprecht I, Zobac P, Suchy P, Cermak B (2008) The probiotic BioPlus $2 \mathrm{~B}$ as an alternative to antibiotics in diets for broiler chickens. Acta Vet Brno 77:569-574

Saki AA, Tabatabie MM, Ahmadi A, Hossenin Sayer SA, Mirzayi S, Kiani N (2006) Nutritive value, metabolizable energy and viscosity of kitchen waste on broiler chicken performance. Pak J Biol Sci 9:1970-1974
Samarasinghe K, Wenk C, Silva KFST, Gunasekera JMDM (2003) Turmeric (Curcuma longa) root powder and mannan oligosaccharides as alternatives to antibiotics in broiler chicken diets. Asian-Aust J Anim Sci 16:1495-1500

Sancho P, Pinacho A, Ramos P, Tejedor C (2004) Microbiological characterization of food residues for animal feeding. Waste Manag 24:919-926

SAS (2003) Statistical analysis system: A User's Guide. Version 9.1 SAS Institute Inc. Cary, NC

Soliman AA, Hamdy S, Khaleel AA, Abaza MA, Akkada AR, ElShazly K (1978) The use of restaurant food waste in poultry nutrition. Alex J Agric Res 26:489-499

Tessi MA, Aringoli EE, Pirovani ME, Vincenzini AZ, Sabbag NG, Costa SC, Garcia CC, Zannier MS, Silva ER, Moguilevsky MA (2002) Microbiological quality and safety of ready-to-eat cooked foods from a centralized school kitchen in Argentina. J Food Prot 65:636-642

Vanderzant C, Splittstoesser DF (1992) Compendium of methods for the microbiological examination of foods, 3rd edn. American Public Health Association, Washington

Walker PM, Hoelting FB, Wertz AE (1998) Fresh pulped food waste replaces supplemental protein and a protein of the dietary energy in total mixed rations for beef cows. Prof Anim Sci 14:207-216

Walker PM, Brown SA, Dust JM, Finnigan DM (2002) Evaluation of feed mixtures amended with processed food waste as feedstuffs for finishing lambs. Prof Anim Sci 18:237-246

Walker PM, Antas AD, Olson JL (2004) Adehydrated mixture containing food waste and wheat middlings serves as a protein and energy substitute in beef cow diets. Prof Anim Sci 20:39-45

Westendorf ML, Dong ZC, Schoknecht PA (1998) Recycled cafeteria food waste as a feed for swine: nutrient content digestibility, growth, and meat quality. J Anim Sci 76:2976-2983

Zhang WF, Li DF, Lu WQ, Yi GF (2003) Effects of isomaltooligosaccharides on broiler performance and intestinal microflora. Poult Sci 82:657-663 